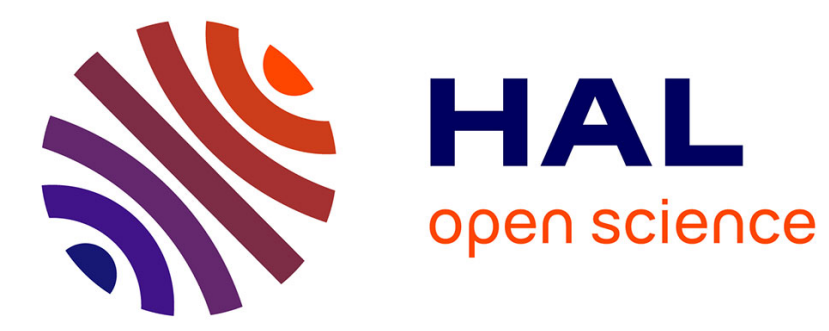

\title{
Dislocations and plasticity (Moderator's Comment)
}

L.M. Brown

\section{To cite this version:}

L.M. Brown. Dislocations and plasticity (Moderator's Comment). Revue de Physique Appliquée, 1988, 23 (4), pp.351-351. 10.1051/rphysap:01988002304035100 . jpa-00245780

\section{HAL Id: jpa-00245780 https://hal.science/jpa-00245780}

Submitted on 1 Jan 1988

HAL is a multi-disciplinary open access archive for the deposit and dissemination of scientific research documents, whether they are published or not. The documents may come from teaching and research institutions in France or abroad, or from public or private research centers.
L'archive ouverte pluridisciplinaire HAL, est destinée au dépôt et à la diffusion de documents scientifiques de niveau recherche, publiés ou non, émanant des établissements d'enseignement et de recherche français ou étrangers, des laboratoires publics ou privés. 


\title{
Dislocations and plasticity (Moderator's Comment)
}

\author{
L.M. Brown
}

University of Cambridge, Department of Physics, Cavendish Laboratory, Cambridge CB3 OHE, G.B.

The papers of this session lead one to hope that the work of physical metallurgists over many years will eventually find its way into theories of plasticity suitable for application in finite-element calculations or models of polyocrystalline behaviour, as proposed by Cailletaud.

A. key element here is the distinction between kinematical hardening and frictional hardening, which may be isotropic or anisotropic. Kinematical hardening is caused by undeformable obstacles, such as are present in dispersion-hardened or fibre composite materials. In the absence of plastic relaxation at the obstacles, the displacement of the yield surface is proportional to the volume fraction of particles, the plastic strain, and accommodation factors dependent on shape, and upon elastic constants. These factors must be calculated by the theory of Eshelby. In this context, kinematical hardening refers to permanent softening, that is, to a displacement of the stress strain curve apparent after large reverse strains. Of course, all hardening mechanisms produce a yield surface whose locus depends upon the reverse strain, or whether one measures the flow stress by a proof stress or by an extrapolation technique. This behaviour is implicit in Orowan's model (1) for the onset of plasticity by the sampling of random obstacles by a moving dislocation. It can be achieved in the Masing model only by postulating several elements.

A central question is: to what extent do the plastic instabilities attendant upon a highly-curved yield surface depend upon the maintenance of that curvature over a macroscopic strain? The shape of the stress-strain curve in the microyield region has been parameterised for particle-containing systems (2). For some problems, the asymmetry of the micro-yield surface upon reverse straining may be important, but the very high slope of the stress-strain curve in the microstrain region will surely stabilise uniform plasticity. However, where permanent softening is large, instabilities may be produced in tension following compression because the work-hardening rate is low, but the stress-level is reduced.

It is important in this context to note that although single-phase materials show rounded stress-strain curves immediately after reversing the plastic strain rate, they show negligeable permanent softening (3). This is interpreted as meaning that the inhomogeneous dislocation tangles are essentially deformable obstacles. They are accompanied by large internal stresses, as Mughrabi shows so clearly in this session.

(1) L.M. Brown on 'Orowan's Exploration of the Bauschinger Effect?' Scripta Met. 11 (1977) 127.

(2) J.D. Atkinson, L.M. Brown and W.M. Stobbs on 'The Work-Hardening of Copper Silica': IV The Bauschinger Effect and Plastic Relaxation, Phil. Mag. 30 (1974) 1247.

(3) O. B. Pedersen, L.M. Brown and W.M. Stobbs on 'The Bauschinger Effect in Copper' Acta Met 29 (1981) 1843. 